\title{
PALAVRAS DO EDITOR
}

Entrego ao leitor o volume 19 (10 semestre-2013) do Caderno Seminal Digital. Seguindo o modelo inaugurado no volume 17, tem-se então um Dossiê Temático sobre o Português como Língua Estrangeira e Temas Afins e uma Miscelânea com artigos de pesquisadores nacionais e estrangeiros.

São relatos de estudos e pesquisas concluídas ou em desenvolvimento, que se debruçam sobre temas de natureza linguística e pedagógica, trazendo à discussão uma variedade de questões que há muito povoam as salas de aula e as academias.

A iniciativa das Publicações Dialogarts é embalada pelo espirito extensionista, cuja meta é abrir as portas da academia e levar, aos mais diversos rincões, a produção de ciência, subsidiada por órgãos públicos e privados, portanto com a obrigação de ser apresentada ao grande público e, possivelmente, servir-lhe de base para redimensionamento de suas práticas ou de inspiração para novas invenções.

A criação dos volumes temáticos do Caderno Seminal Digital vem responder a demanda de submissões decorrentes de encontros acadêmicos no Brasil e no estrangeiro. Esclarecemos, ainda, que o conteúdo técnico-científico dos artigos, bem como sua expressão linguística, são de inteira responsabilidade dos autores.

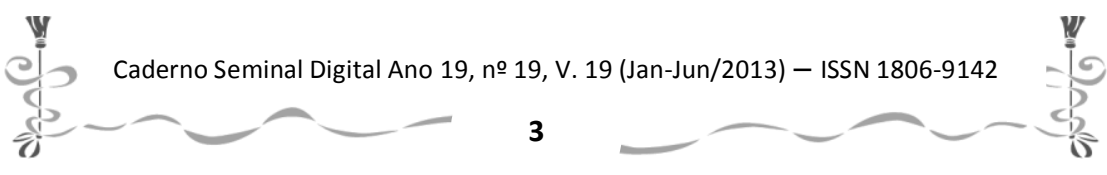


Caderno Seminal Digital

Seguindo o objetivo de nosso projeto editorial, buscamos reunir textos de qualidade e autoridade acadêmica que possam dar suporte ao ensino na graduação e na pósgraduação, consolidando o tripé em que devem assentar-se as Universidades: Ensino, Pesquisa e Extensão.

Darcilia Simões UERJ/CNPq/SELEPROT 